৩コメント

\title{
名古屋大学 江崎光男
}

報告論文は，東アジア経済危機を通貨危機の第 1 段階と構造調整の第 2 段階

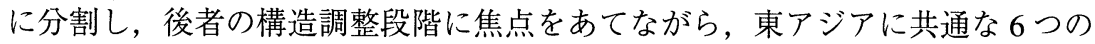
構造問題を指摘し，全要素生産性（TFP）の視点からその成長ポテンシャルを 探っている。議論の出発点は，P.クルーグマン教授の「幻のアジア経済」，す なわち投入増大型成長あるいは低いTFP成長のもつ限界である。6つの構造問 題とは，貿易構造問題（輸入依存度の高い輸出）, 産業構造問題（弱い産業連 関)，金融構造問題（規模と制度のミスマッチ），国際標準への組み込み，弱い アジアの域内協力, 自助努力の欠如である。議論の締めくくりは, 再び, クル ーグマン氏の投入増大型成長である。同氏のブルドーザーとショベルの例，お よび小島清教授の「自国経営者による自力主導開発に重点を移して行くべきで ある」等を引用しながら, 自らの創意工夫, 知識と知恵の増大, 生産性上昇運 動，労働意欲の増大により，輸出競争力をつけ，国内産業を強くし，すそ野を 広げてゆく「新輸入代替戦略」を提言する。それは，一言で言えば，自らの TFPの上昇を総力をあげて追求する戦略である。

この新戦略は, 自助努力（外資依存からの脱却）と TFPの上昇（投入増大型 成長の転換）を基本的要素にして，6つの構造問題を組み合わせながら, 説得 的に提言されている。ただし，前者の自助努力の課題については，食糧自給や 製造業対サービス業の議論に類似した政治・哲学的内容が含まれており，決着 がつけ難い論争に帰着するのではないだろうか。純経済的にみる場合，東アジ アの成長や技術的キャッチアップに果たす直接投資の役割は依然として重要で あり，外資依存の低下あるいは外資系と民族系企業の共存は，経済・社会発展 と共に徐々に実現されるであろうと, 討論者は予想する。後者のTFP上昇の課 題についても, 報告論文のTFP論争のレビューから理解されるように, TFPの 内容を明確に規定しない限り, 決着のつけ難い論争に終わるだろう。ここでは, TFPの内容を, 資源配分の改善・規模の経済性・知識の向上というデニソン型 
の要因に限定し, 以下のように問題を設定し直して, やや詳細にコメントした い。すなわち，(1)東アジアのTFP成長は本当に低かったのか。(2)過去にTFP成 長が低かったとしても, 将来もそうなのか。(3)将来TFPが上昇する可能性があ るとすれば，いつ，どのようにして可能になるのか。

設問(1)対する答えは恐らくYESである。まずタイについて，ブラニー\&チ ヤロンポップ両氏の詳細な生産性研究（TDRI, 1996）によれば，1978一90年の 期間に対して, GDP成長は $7.6 \%$, 労働の貢献は $26 \%$ （質調整前）あるいは $46 \%$ (質調整後), 土地・資本の貢献は $38 \%, \mathrm{TFP}$ 貢献36\%は（質調整前） あるいは $16 \%$ (質調整後) のように計測されている。また, 討論者は, 資本ス トックとTFP成長を同時に推計する新しい方法論（江崎・孫林，1998）に基づ き，東アジア 9 カ国の成長会計分析を1972一96年の期間に対して試み，GDP成 長率とそれに対するTFP 貢献度を，中国10.1\%，24\%（1980-96），インドネ シア $6.8 \%, 6 \%(1978-96)$, フィリピン $2.3 \%,-16 \%(1980-96)$, マレー シア $7.4 \%,-11 \%$, 夕イ $7.6 \%, 15 \%$, 韓国 $8.6 \%, 23 \%$, 台湾 $8.0 \%, 11 \%$, 香 港7.4\%, 17\%, シンガポール $8.1 \% ， 26 \%$ のうに計測した。

設問(2)に対する答えは恐らく，NOである。速水佑次郎教授（『開発経済学』 1995）は，明治以降の日本の経済発展を，1931年以前のマルクス型成長とそれ 以後のクズネッ型成長に 2 分した。前者は投入増大型成長で資本の分配率が上 昇し, 後者はTFP主導型成長で労働分配率が上昇する。米国でも1890年を境に して同様の成長パターンの転換が生じている。成長パターンの移行要因につい ては, シュンペーター流の企業家と新結合が強調されている。現時点で投入依 存型の成長に段階にあると思われる東アジア諸国も, 遅かれ早かれ, TFP主導 の成長段階に移行することが予想される。

従って, 設問(3)あるように, 問題は, いつどのようにして成長パターンの 転換に起こるかである。そのような転換は, 恐らく, 東アジア各国の経済社会 の発展段階に対応して，少なくとも漸進的に生じつつあると思われるが，その 重要な担い手の 1 つが多国籍企業であることは言うまでもない。また，CP 
（チャラン・ポカパン）のような民族系多国籍企業もある。更に, 曲芸飛行型 とみられるモトローラやミネベアのような外資もある。一般に，中長期的には， 比較優位の変化に基づく雁行形態型発展による産業構造の変化がTFPの押し上 げる基本的要因になると考えられる。そして，以上を支援する社会発展が着実 に進行中である。例えば, 夕イの高校進学率は, 既に同世代の $60 \%$ に達してい る。

\section{[参考文献]}

Pranee Tinakorn and Chalongphob Sussangkarn, Productivity Growth in Thailand, Thailand Development Research Institute, 1996.

江崎光男・孫林「中国経済の成長会計分析（1981-95年)」, 『国際開発研究フォーラーム』 10, 1998年 7 月。

速水佑次郎『開発経済学』, 創文社, 1995年。 